\title{
Gece Çalışması ve Gece Çalışma Süresinin Sınırı ile İlgili Değişikliklerin Değerlendirilmesi
}

\author{
Ayşe Ledün Akdeniz* (1)
}

\section{Öz}

Gece döneminde çalışmanın, toplum bakımından bir ihtiyaç olduğu kabul edilmektedir. Ancak bu çalışma biçimi, özellikle çalışanların sağlığı üzerindeki olumsuz etkileri nedeniyle önemli tartışmaları da beraberinde getirmektedir. Bu nedenle gece çalışmalarına ilişkin olarak pek çok sınırlandırıcı hüküm bulunmaktadır. Bunlardan biri de gece çalışma süresine ilişkin sınırdır. 2015 yılında İş Kanunu'nda yapılan değişiklik sonucunda, belirli sektörlerde (turizm, özel güvenlik ve sağlık hizmetlerinin yürütüldüğü işlerde) gece çalışma süresi sınırının aşıımasına imkân tanıyan bir düzenleme yürürlüğe girmiştir. Bu değişiklik, gece çalışması ile ilgili yönetmeliklerin de revize edilmesini gerektirmiştir. Yeni düzenleme uyarınca her ne kadar yedi buçuk saatin üzerinde gece çalışması yaptırılabilmesi için iş̧̧inin yazılı onayının alınması şart koşulmuş ise de, yapılan değişikliklerin işçi bakımından yeterli bir koruma sağladığından söz etmek güç gözükmektedir. Çalışmamızda, gece çalışmasının genel özellikleri ile gece çalışmalarına ilişkin bazı tartş̧malı noktalara yer verilmiştir. Böylelikle gece çalışmasına ilişkin son değişikliklerin, konu hakkındaki mevcut tartışmalar ile bağlantılı bir biçimde değerlendirilmesi ve tespit edilen sorunlara çözüm önerileri sunulması amaçlanmıştır.

\section{Anahtar Kelimeler \\ Gece çalışması, Çalışma süresi, Postalar halinde çalışma, Turizm, Özel güvenlik, Sağlık hizmeti}

\section{Night Work and The Evaluation of the Amendments Regarding the Limit of Night Work Period}

\begin{abstract}
It is stated that night work is a necessity in terms of the community. However, this type of work leads on to important discussions, particularly due to its negative impacts on the health of the workers. Thus, there are many restrictive provisions with respect to night work, one of which is related to the limit regarding the night work period. With the amendments made in $\mathbf{2 0 1 5}$ to the Labor Law, a new provision allowing for the limit to be exceeded regarding the night work period in some sectors (tourism, private security and jobs related to healthcare) entered into force. This amendment required revisions in other regulations concerning night work as well. Although it is now stipulated, in accordance with the amendments, that the worker's approval in writing must be obtained in order to perform night work for more than seven hours and a half, it seems hard to indicate that such amendments provide adequate protection to the workers. Our study contains the general characteristics of night work, and some discussions with respect thereto. Accordingly, it is aimed to evaluate the last amendments introduced regarding night work in connection with the current discussions on the subject, and to provide solutions to the identified problems.
\end{abstract}

\section{Keywords}

Night work, Working time, Shift work, Tourism, Private security, Healthcare

\footnotetext{
Sorumlu Yazar: Ayşe Ledün Akdeniz (Arş. Gör. Dr.), İstanbul, Üniversitesi Hukuk Fakültesi, İş ve Sosyal Güvenlik Hukuku Anabilim Dalı, İstanbul, Türkiye. E-Posta: alakdeniz@istanbul.edu.tr ORCID: 0000-0002-1312-3726
}

Atıf: Akdeniz AL, “Gece Çalışması ve Gece Çalışma Süresinin Sınırı ile İlgili Değişikliklerin Değerlendirilmesi” (2019) 77(2) İstanbul Hukuk Mecmuası 555. https://doi.org/10.26650/mecmua.2019.77.2.0004 


\section{Extended Summary}

Night work has been the subject of many discussions due to its contradictory nature to the biological structure of the human body. This attribute of night work requires that night work and day work should not be handled in the same way in the legal order. The developments in the field of Occupational Health and Safety Law, and the researches regarding the effects of night work on the human health, constantly demand the review and improvement of the regulations regarding night work. In this regard, the most important protective provision regarding the workers working at night could be the limit on the night working time.

In accordance with the Article 69 (I) of the Labour Law No. 4857, "night" is defined as the period starting at the latest at 20.00 in the evening, and lasting at the earliest until 06.00 in the morning, which in any case lasts maximum eleven hours. Furthermore, in accordance with Article 69 (III), night work shall not exceed seven and a half hours. However, significant exceptions have been recently adopted to this rule. The amendment, enacted in 2015, allows employers in some sectors (private security, tourism and jobs related to healthcare) to demand night work in excess of seven and a half hours by obtaining written approval from the worker. It should be noted that the regulations concerning night work are particularly important regarding the work carried out by shift work. Taking into consideration the need for governing special procedures and principles on this subject, a regulation specifically on shift work has been issued, and exceptions to the rule on the limit of the night working time are also included in this regulation.

In my opinion, the propriety of this change amendment is highly debatable. It can be argued that the service should continue uninterruptedly in the sectors mentioned in the Article (private security, tourism and jobs related to healthcare). However, the employment of the workers for longer periods is not the only way to ensure the continuity of the service. Although written approval of the worker enabling the night work in excess of seven and a half hours is stipulated, the worker-protective approach of the Labour Law which protects the workers even from themselves, especially on the issues regarding occupational health and safety should not be disregarded.

It should also be noted that the Regulation on shift work also includes a statement which is not included in the text of the Labour Law. In the Regulation; it is prescribed that the workers employed by the subcontractor in the workplaces, where private security, tourism and health services are carried out, also fall under this scope. If the letter of the statement is followed; it could be concluded that all workers employed by the subcontractor in the health, tourism and private security sectors may be employed at night for more than seven and a half hours. However, it is clear that such an interpretation would be incompatible with the exception regulated in the Labour 
Law. The provision of the regulation should be interpreted in a manner to cover subcontractor workers who are employed in the sectors referred to in the Labour Law, specifically in cases where subcontracted work is carried out with respect to these sectors.

It has been concluded that the recent changes in the field of night work constitute a reversal in terms of workers' rights. It is clear that the continuity of the services without disruption can be also maintained by increasing the number of shifts. Furthermore, I would like to draw attention to the fact that the regulations regarding night work are quite disorganized. In this regard, it may be suggested that all the rules regarding night work should fall into a single regulation. As a result, it may be stated that there is a need for the review of the regulations on night work in our legislation. 


\section{Gece Çalışması ve Gece Çalışma Süresinin Sınırı ile İlgili Değişikliklerin Değerlendirilmesi}

\section{Giriş}

Gece çalışması, insanın biyolojik yapısına ters düşen niteliği nedeniyle, pek çok tartışmaya zemin oluşturan bir çalı̧̧ma biçimidir. Hukuk düzeninde, toplumun ihtiyaçlarının sağlanabilmesi amacı ile gece çalışmaları yapılmasına izin verilmekte ise de, bu çalışma biçimine ilişkin pek çok sınırlandırıcı hüküm de bulunmaktadır. Çalışmamızda, gece çalışmasının özelliklerine yer verilerek, 6645 sayılı Kanun ${ }^{1}$ ile gece çalışması bakımından yürürlüğe giren ve gece çalışma süresi sınırının belirli işler bakımından aşılmasına imkân tanıyan değişikliğin incelenmesi amaçlanmaktadır.

\section{II. İş Kanunu'nda “Gece Çalışması"}

Gece çalışması, işçi ve işveren arasındaki iş ilişkilerinin büyük çoğunluğu² bakımından uygulama alanı bulan 4857 sayılı İş Kanunu'nun ${ }^{3}$ 69. maddesinde düzenlenmektedir. Maddenin gerekçesinde de yer verilmiş olduğu üzere, hükmün içeriği oluşturulurken, 1475 say1lı İş Kanunu'nun ${ }^{4}$ mülga 65. maddesinde yer verilen esaslar kural olarak aynı şekilde korunmuştur. Esasen, 1475 sayılı İş Kanunu'nun mülga 65. maddesi de, mülga 3008 sayılı Kanun'un ${ }^{5}$ 43. maddesi ile benzerlikler içermektedir. Böylelikle her şeyden önce, İş Kanunu'nda gece çalışmasına yönelik esasların uzun bir süredir önemli bir değişikliğe uğramaksızın korunduğunu tespit etmek mümkündür6́.

\footnotetext{
İş Sağlığı ve Güvenliği Kanunu ile Bazı Kanun ve Kanun Hükmünde Kararnamelerde Değişiklik Yapılmasına Dair Kanun, Kanun Numarası: 6645, Kabul Tarihi: 4.4.2015, RG 23.4.2015/29335.

2 Hukuk düzenimizde, 854 sayılı Deniz İş Kanunu’na, 5953 sayılı Basın Mesleğinde Çalışanlarla Çalıştıranlar Arasındaki Münasebetlerin Tanzimi Hakkında Kanun'a ve 6098 sayılı Türk Borçlar Kanunu'na tabi olan iş iliş̧ileri de bulunduğundan, bir gece çalışması söz konusu olduğunda, öncelikle, işgörme borcunu yerine getiren ișçinin hangi Kanun'a tabi olduğunun belirlenmesi ve uygulama alanı bulacak Kanun'da gece çalışmasına ilişkin bir hüküm bulunup bulunmadığının tespiti önem taşımaktadır. Belirtelim ki, Borçlar Kanunu gece çalışmasına yönelik herhangi bir düzenleme içermemektedir. Deniz İş Kanunu'nda ise, iş süresine yönelik hükme yer verilmişse de, gece çalışması ayrıca düzenlenmemiştir. Bununla birlikte Gemiadamları ve Kılavuz Kaptanlar Yönetmeliği (RG 10.2.2018/30328) madde 60/5’te, gece dönemi, 4857 sayılı İş Kanunu'ndaki esaslara paralel bir biçimde, en geç akşam saat 20.00'de başlayan, en erken sabah saat 06.00'a kadar süren ve her durumda en fazla on bir saat sürebilen dönem olarak belirlenmiştir. Benzer şekilde, Basın İş Kanunu'nda da gece çalışması ayrıca tanımlanmamıştır fakat gece çalışmasına yönelik bazı özel düzenlemelere yer verildiğinden konunun dolaylı yönden ele alındığı sonucuna varılmaktadır, bu yönde bkz Vuslat Özyurt, 'Gece Çalışması ve Postalar Halinde Çalışma’ (2008) 5 (19) Legal İHSGHD 919, 950. Bu anlamda Basın İş Kanunu madde 19 örnek gösterilebilir. Yine, bu Kanun anlamında gazeteci kavramına dâhil olanlardan müessese, matbaa, idarehane ve büro gibi yerlerde hizmetlerinin niteliği itibariyle aralıksız bir biçimde çalışanlar bakımından günlük iş süresi, gece ve gündüz dönemlerinde sekiz saat olarak belirlenmiş, gece veya gündüz dönemindeki çalışma süresinin artırılması durumunda bu Kanuna göre fazla çalışma sayılacağı öngörülmüştür (bkz Ek madde 1).

3 İș Kanunu, Kanun Numaras1: 4857, Kabul Tarihi: 22.5.2003, RG 10.6.2003/25134.

4 İş Kanunu, Kanun Numarası: 1475, Kabul Tarihi: 25.8.1971, RG 1.9.1971/13943.

İş Kanunu, Kanun Numarası: 3008, Kabul Tarihi: 8.6.1936, RG 15.6.1936/3330.

6 Bununla birlikte, mülga 3008 sayılı İş Kanunu'nda yer verilen düzenlemede (4857 ve 1475 sayılı İş Kanunlarından farklı olarak) işçilerin gece çalışmalarının "sekiz saatten" fazla süremeyeceğinin öngörülmüş olduğu da eklenmelidir.
} 
İş Kanunu madde 69/I'de ${ }^{7}$ gece; en geç akşam saat 20.00 'de başlayan, en erken sabah saat 06.00 'ya kadar süren ve her durumda da en fazla 11 saat süren dönem olarak tanımlanmıştır. Bu tanımda yer verilen "en erken", "en geç" ve "en fazla 11 saat" ifadeleri gece döneminin başladığı saat ile biteceği saatin değiştirilebileceğini, ancak devam süresinin en fazla 11 saate kadar çıkarılabileceğini ifade etmektedir ${ }^{8,9}$. $\mathrm{Bu}$ noktada ekleyelim ki, hukukumuzda çalışma süresi kavramı bakımından, gece döneminde çalışma süresi ile gündüz dönemi çalışma süresi gibi bir ayrım yapılmamaktadır ${ }^{10}$. Çalışmanın Kanun'da belirtilen zaman dilimine denk gelmesi durumunda, gerçekleştirilen çalışma bakımından gece çalışmasının hükümleri uygulama alanı bulmaktadır ${ }^{11}$.

\section{Gece Çalışmasının Özel Durumu ve Süresinin Daha Kısıtlı Tutulması İhtiyacı}

Gece çalışmasının, uygulamaya geçtiğinden beri tartışmalara yol açmış bir çalışma olduğu ifade edilmektedir ${ }^{12}$. Gece çalışmalarının insan sağlığı üzerinde olumsuz etkilerine ve sebebiyet verdiği hastalıklara ilişkin pek çok araştırma bulunmaktadır ${ }^{13}$. Öğretide de isabetle dikkat çekildiği üzere insan, gece uyumasını gerektiren bir biyolojik yapıya sahiptirr ${ }^{14}$; gece çalışması ise bu yapıya aykırı niteliktedir. O halde bir gece çalışması söz konusu olduğunda, bu çalışma biçiminin gündüz çalışması ile bir tutulamayacağı konusunda tereddüt etmemek gerekir ${ }^{15}$. Nitekim bu doğrultuda, gece çalışmaları özellik arz eden çalışma süreleri olarak ele alınmakta ${ }^{16}$ ve genellikle konunun iş sağllğ 1 ve güvenliği ile yakından ilgisine ${ }^{17}$ de yer verilmektedir.

1475 sayılı İş Kanunu'nun mülga 65. maddesinin kenar başlığı “Gece Süresi” başlığını taşımakta idi. 4857 sayılı Kanun'un 69. maddesinin gerekçesinde, madde başlığında yapılan değişiklik gerekçesine de yer verilmiştir. Buna göre anılan maddede gece süresi tanımının yanı sıra, gece çalışmalarının ne şekilde yapılacağı da düzenlenmiş olduğu için, madde başlı̆̆ "Gece Süresi ve Gece Çalışmaları" olarak değişikliğe uğramıştır.

8 Münir Ekonomi, İş Hukuku, Cilt 1 (3rd edn, Teknik Üniversitesi Matbaası 1984, 288; Ercan Güven and Ufuk Aydın, Bireysel İş Hukuku (5th edn, Nisan 2017, 273; Hamdi Mollamahmutoğlu, Muhittin Astarlı and Ulaş Baysal, İş Hukuku Ders Kitabl, Cilt 1: Bireysel İş Hukuku (3rd edn, Lykeion 2019) 349; Zeki Okur, 'İş Hukuku'nda Gece Çalışması', Prof. Dr. Ali Güzel'e Armağan, Cilt I, (Beta 2010) 511, 512; Murat Özveri, 'Çalışma Süresi ve Gece Çalışması', Prof. Dr. Ali Güzel'e Armağan, Cilt I, (Beta 2010) 623, 629.

9 Bu tanım, yeterli açıklık taşımaması yönünden eleştiriye uğramıştır, bkz Muhittin Astarlı, İş Hukukunda Çalışma Süreleri (Turhan 2008) 256.

10 Baki Oğuz Mülayim, İ̧̧ Hukukunda Gece Çalışması (Adalet 2016) 146; Mollamahmutoğlu, Astarlı and Baysal, Işs Hukuku (n 8) 348.

11 Serkan Odaman, Esneklik Prensibi Çerçevesinde Yargıtay Kararları Ișığında Türk İş Hukukunda Çalışma Süreleri ve Yöntemleri (Legal 2013) 85.

12 Özveri, 'Gece Çalışması' (n 8) 626.

13 ibid 627. Gece çalışmasının işçi sağlığı üzerinde olumsuz etkilerinin vardiyalı ya da sürekli gece çalışması yapılması fark etmeksizin ortaya çıtı̆̆ yönünde, bkz ibid 627.

14 Okur, 'Gece Çalışması' (n 8) 511; Astarlı, Çalışma Süreleri (n 9) 251.

15 Bu konuda bakınız Nüket Saracel, Gece Çalışması ve Türk İş Hukukunda Gece Çalışmasının Düzenlenme Esasları (T.C. Anadolu Üniversitesi Yayınları 1987) 29 ff.

16 Sarper Süzek, ISŞ Hukuku (18th edn, Beta 2019) 778; Astarlı, Çalışma Süreleri (n 9) 251; Okur, 'Gece Çalışması' (n 8) 514

17 Gece çalışma süresi de dâhil, iş sürelerinin, iş sağlığı ve güvenliği bakımından öneminin özel düzenlemelerin kabulünü gerektirdiği yönünde bkz Gülsevil Alpagut: 'İş Kanunu Kapsamında Çalışma ve Dinlenme Süreleri - Yargılama Sürecinde Emsal Ücret Sorunu', Ișs Uyușmazlıklarında Yargıtay ve Bölge Adliye Mahkemeleri Kararları Değerlendirme Toplantısı (INTES 2019) 68. Ayrıca en büyük sanayi kazalarının da gece çalışmasında yaşandığı yönünde bkz Bünyamin Bacak 
Mevzuatımızda gece çalışma süresi bakımından getirilmiş ana kural İş Kanunu madde 69/III'te yer almakta olup, buna göre gece çalışmasının kural olarak yedi buçuk saati geçmemesi gerekir. Ancak bu ana kurala yakın geçmişte ${ }^{18}$ önemli istisnalar getirilmiştir. İş Kanunu madde 69/III'e eklenen cümle uyarınca; özel güvenlik, turizm ve sağlık hizmetlerinin yürütüldüğü işlerde işçiden yazılı onayını almak şartıyla yedi buçuk saati aşacak şekilde gece çalışması yaptırılabilmesi artık yasal hale gelmiştir. Bununla birlikte, anılan sektörlerde yedi buçuk saat üzerinde gece çalışması yapılmasına imkân tanınmış ise de, günlük çalışma süresine yönelik 11 saatlik sınırın (bkz. İş Kanunu madde 63/II, İş Kanununa İlişkin Çalışma Süreleri Yönetmeliği ${ }^{19}$ madde 4/III) halen yürürlükte olduğu da belirtilmelidir. Ayrıca mevzuatımızda iş sağlığı ve güvenliğine yönelik başkaca düzenlemelerin yürürlükte oldukları da gözden kaçırılmamalıdır. Bu bakımdan örneğin, Sağlık Kuralları Bakımından Günde Azami Yedi Buçuk Saat veya Daha Az Çalışılması Gereken İşler Hakkında Yönetmelik’te ${ }^{20}$ öngörülen sınırlamalara uyulması gerekli olup, bu kapsamda korunmuş işçiler yazılı onay vermiş olsalar bile, yedi buçuk saatin üzerinde çalışamazlar ${ }^{21}$.

Ekleyelim ki, işçilerin gece postalarında yedi buçuk saatten çok çalıştırılmalarının yasak olduğuna ilişkin ana kurala, Postalar Halinde İşçi Çalıştırılarak Yürütülen İşlerde Çalışmalara İlişkin Özel Usul ve Esaslar Hakkında Yönetmelik ${ }^{22}$ madde 7'de de yer verilmiş ve yine bu maddede bu kurala bazı istisnalar getirilmiştir. Maddede yer verilen ilk istisna, zorunlu nedenlerle fazla çalışma yapılması gereken haller ile olağanüstü hallerde fazla çalışma yapılmasını gerektiren hallere ilişkindir (bkz. İş Kanunu madde 42 ve 43). Böylelikle işçilerin postalar halinde çalıştırılması ile yürütülen işlerde, İş Kanunu'na tabi çalışan işçinin fazla çalışma yapmasının onun onayına bağlanmadığı hallerden biri söz konusu olduğunda, gece çalışması da yedi buçuk saatten fazla sürebilecektir. İkinci olarak, Hazırlama, Tamamlama ve Temizleme İşleri Yönetmeliği'nde ${ }^{23}$ belirtilen durumlarda da gece postasında yedi buçuk saatten fazla çalıştırma yaptırılabileceği öngörülmektedir ${ }^{24}$. Maddede yer

and Ecehan Kazancı, 'Türk Çalışma Hayatında Vardiyalı Gece Çalışan İşçilerin Karşılaştığı Fizyolojik, Psikolojik Ve Sosyolojik Etkilerin Değerlendirilmesi’ (2014) 3 (6) Emek ve Toplum 132, 134. Gece çalışmasına ilişkin özel kurallar öngörülmesinin nedeninin, işçilerin korunması ihtiyacı ile ilgili olduğu yönünde bkz E. Tuncay Senyen- Kaplan, Bireysel $\dot{I S S ̧ S ~}_{S}$ Hukuku (10th edn. Gazi 2019) 373; Güven and Aydın, Bireysel İş Hukuku (n 8) 273; Mollamahmutoğlu, Astarlı and Baysal, İş Hukuku (n 8) 348; Sevgi Dursun Ateş, 'Turizm, Özel Güvenlik Ve Sağlık Hizmeti Yürütülen İşlerde Gece Döneminde Yapılan Çalışmalar' (2019) 16 (61) Legal İHSGHD 81, 81, 90-91.

18 Bkz İş Sağlığı ve Güvenliği Kanunu ile Bazı Kanun ve Kanun Hükmünde Kararnamelerde Değişiklik Yapılmasına Dair Kanun madde 37, Kanun Numarasi: 6645, Kabul Tarihi: 4.4.2015, RG 23.4.2015/29335.

19 İş Kanununa İlişkin Çalışma Süreleri Yönetmeliği, RG 6.4.2004/25425.

20 Sağlık Kuralları Bakımından Günde Azami Yedi Buçuk Saat veya Daha Az Çalışılması Gereken İşler Hakkında Yönetmelik, RG 16.7.2013/28709.

21 Dursun Ateş, 'Gece Döneminde Yapılan Çalışmalar' (n 17) 103.

22 Postalar Halinde İşçi Çalıştırılarak Yürütülen İşlerde Çalışmalara İlişkin Özel Usul ve Esaslar Hakkında Yönetmelik, RG 7.4.2004/25426.

23 Hazırlama, Tamamlama ve Temizleme İşleri Yönetmeliği, RG 28.4.2004/25446.

24 İlgili Yönetmelik' in 5. maddesi uyarınca Kanun'a göre asıl işe göre belirlenmiş günlük çalışma süresine ilave olarak, bu sürenin başlama saatinden önce ya da bitme saatinden sonra olmak üzere, hazırlama, tamamlama ve temizleme işlerini görecek işçiler, anılan işlerde günde en fazla iki saat daha çalıştırılabileceklerdir. Ekleyelim ki, bu Yönetmelik kapsamında 
verilen son istisna ise, 2015 yılındaki Kanun değişikliğini ${ }^{25}$ takiben, bu Yönetmelik’te yapılan değişiklik ile tanınmışıır' ${ }^{26}$. Çalışmamızda, gece çalışmasının yedi buçuk saati aşmasına belirli sektörler bakımından izin veren söz konusu değişikliğin incelenmesi amaçlanmaktadır. Ancak son değişikliklerin mevcut tartışmalar ile bağlantılı bir biçimde değerlendirilebilmesi için, öncelikle gece çalışmalarına ilişkin bazı hususlara yer verilmesi uygun görülmüştür.

\section{Gece Çalışma Süresi Bakımından Bazı Tartışmalı Noktalar}

Postalar halinde çalışma, üretimde kullanılan teknik nedeniyle üretime kesintisiz bir biçimde devam edilmesi gerektiğinde başvurulan bir çalışma düzenidir ${ }^{27}$. Hukukumuzda bu konuya ilişkin özel usul ve esaslar düzenlenmesi ihtiyacı gözetilerek, postalar halinde çalıştırılma suretiyle yürütülen işlere özgü bir yönetmelik çıkarılmıştır. Bu Yönetmelik niteliği itibarıyla sürekli çalıştıkları için kesinti olmaksızın üst üste postalar halinde işçi çalıştırılmak usulü ile işletilen işleri veya nöbetleşe şekilde işçi postalarıla yerine getirilen işleri kapsamaktadır. Söz konusu yönetmelikte gece postalarına ilişkin de esaslara yer verilmiştir ${ }^{28}$. Gerçekten, gece çalışmasına ilişkin düzenlemeler, özellikle nöbetleşe işçi postaları ile yapılan işler bakımından önem arz etmektedir. Yönetmelik'te yer verilen esaslardan biri de, çalışma süresi hesaplanırken bu sürenin yarısından fazlasının gece dönemine rastlayan bir posta çalışmasının gece çalışması sayılacağıdır (madde 7/son). Bu doğrultuda öğretide, postalar halinde çalışmalarda gece çalışmasından söz edebilmek için, çalışma süresinin yarısından fazlasının gece dönemine rastlamasının yeterli olduğuna dikkat çekilmiş ve bu anlamda posta vardiyasının 20.00 ve 06.00 saatleri arasında başlamasının ya da bitmesinin beklenmediği isabetli olarak ifade edilmiştir ${ }^{29}$. Bu zaman dilimleri ile temas etmek kaydıyla, bir posta çalışması süresinin yarısından fazlası gece dönemine rastlamakta ise bu çalışma gece çalışması sayılmaktadır.

$\mathrm{Bu}$ noktada, gece dönemi ile gündüz dönemine rastlayan çalışma sürelerinin eşit olması halinde bir çalışmanın ne şekilde nitelendirileceği konusunun öğretide tartışmalı

bir hazırlama, tamamlama ve temizleme çalışmanın yaptırılabilmesi için Yönetmelik'te belirlenen diğer koşulların da sağlanması gerekir.

25 Bkz İş Sağlığı ve Güvenliği Kanunu ile Bazı Kanun ve Kanun Hükmünde Kararnamelerde Değişiklik Yapılmasına Dair Kanun madde 37.

26 Değişiklik yapan Yönetmelik için bkz Postalar Halinde İşçi Çalıştırılarak Yürütülen İşlerde Çalışmalara İlişkin Özel Usul ve Esaslar Hakkında Yönetmelikte Değişiklik Yapılmasına Dair Yönetmelik, RG 19.8.2017/30159.

27 Okur, 'Gece Çalışması' (n 8) 511.

28 Örneğin Yönetmelik'in 4. maddesi uyarınca, nitelikleri nedeniyle sürekli çalıştıkları için kesintisiz olarak üst üste postalar halinde işçi çalıştııılarak yürütülen işler bakımından posta sayısı 24 saatlik süre içerisinde en az üç posta olacak şekilde düzenlenmelidir. Ancak aynı maddede yapılan değişiklik uyarınca; özel güvenlik, turizm ve sağlık hizmetlerinin yürütüldüğ̈ü işlerde ve bu işlerin yürütüldüğü işyerlerinde faaliyette bulunan alt işverence yürütülen işlerde düzenleme 24 saat içerisinde iki posta olacak şekilde yapılabilecektir. Değişiklik yapan Yönetmelik için bkz RG 19.8.2017/30159. Bu şekilde 24 saat içerisinde iki posta olacak şekilde çalışılması, anılan işlerde gece çalışma süresinin yedi buçuk saatin üzerinde kararlaştırılabilmesi ile bağlantılıdır.

29 Ömer Ekmekçi, ‘4857 Sayılı İş Kanunu’nda Postalar Halinde Çalışma ve Gece Çalışmasına İlişkin Usul ve Esaslar’ (2006) Çimento İşveren, 48, 50. 
olduğunu da eklemek gerekir. Bir görüşe göre, postalar halinde işçi çalıştırılmasına ilişkin Yönetmelik’te "çalışma süresinin yarısından çoğu gece dönemine rastlayan bir postanın gece çalışması sayılacağından" söz edileceği açıkça belirtilmiş olduğundan (bkz. madde 7/son), gece dönemi ve gündüz dönemine denk gelen çalışma sürelerinin eşitliği halinde, çalışma, gece çalışması olarak nitelendirilmemelidir ${ }^{30}$. Görüşümüze göre de, gece dönemi ve gündüz dönemine denk gelen çalışma sürelerinin eşit olması halinde çalışmanın gece çalışması sayılabilmesi için bir mevzuat değişikliği gerekli olup yürürlükteki mevzuat çerçevesinde bu durumun gece çalışması olarak değerlendirilmesi imkânı bulunmamaktadır. Bununla birlikte aksi yöndeki görüşe göre, işçi yararına yorum ilkesi kapsamında, gece dönemi ve gündüz dönemine denk gelen çalışma sürelerinin eşit olması halinde bu çalışmanın gece çalışması olarak kabul edilmesi gerekir ${ }^{31}$.

Yine, Yönetmelik'in ilgili maddesinde, çalışma süresinin yarısından çoğunun gece dönemine rastlamasından söz edildiğine de dikkat çekmek isteriz. Öğretide bu ifadeden hareket ile, ara dinlenme süresinin gece çalışması süresinin hesabında dikkate alınmaması gerektiği ileri sürülmektedir ${ }^{32}$. Gerçekten, İş Kanunu madde 68/son ve İş Kanununa İlişkin Çalışma Süreleri Yönetmeliği madde 3/I uyarınca ara dinlenmelerinin çalışma süresinden sayılması imkânı bulunmamaktadır. Ancak görüşümüze göre, gece çalışmaları söz konusu olduğunda, meselenin gündüz çalışmaları ile aynı şekilde ele alınmış olması eleştirilebilir bir durumdur. Gece çalışmasında bulunan bir işçi ara dinlenmesi verdiğinde, yalnızca mola vermemekte, aynı zamanda biyolojik yapısına ters düşen bir biçimde gün 1şı̆̆ından yoksun bir şekilde geçireceği süreyi de uzatmaktadır. Bu nedenle kanaatimizce, ara dinlenmelerinin gece çalışma süresine dâhil edilmesi yönünde bir mevzuat değişikliği yapılması isabetli olacaktır.

Öte yandan, gece çalışmasının mutlaka postalar (vardiyalar) halinde yürütülmesinin bir zorunluluk olmadığına da dikkat çekilmelidir. Bir işçinin sürekli olarak gece çalışması yapması da olasıdır ${ }^{33}$. Örneğin gece çalışması yapılmayan bir işyerinde, güvenliği sağlamak amacıyla yalnızca ve sürekli bir biçimde gece bekçisi olarak çalışan bir işçi bakımından durum bu şekildedir. Açıktır ki, posta usulü olmaksızın sürekli biçimde gece çalışan bir işçinin çalışmasının bir kısmının gündüz dönemine, bir kısmının ise gece dönemine rastlaması da söz konusu olabilecektir. Ancak bu şekilde bir durum söz konusu olduğunda çalışmanın ne şekilde nitelendirileceğine yönelik bir düzenleme mevzuatımızda yer almamaktadır. Çalışılan sürenin yarısından fazlasının gece dönemine denk geldiği bir posta çalışmasının gece çalışması sayılacağı, sadece

\footnotetext{
30 ibid 51; Okur, 'Gece Çalışması' (n 8) 513, Mülayim, Gece Çalışması (n 10) 141.

31 Nuri Çelik, Nurșen Caniklioğlu and Talat Canbolat $\dot{I}_{S}$ Hukuku Dersleri (32th edn, Beta 2019) 706; Öner Eyrenci, Savaș Taşkent and Devrim Ulucan, Bireysel İ̧̧ Hukuku (9th edn, Beta 2019) 317; Fevzi Demir, En Son Yargıtay Kararları Işı̆̆ında İş Hukuku Ve Uygulaması (8th edn, Albi 2014) 235; Dursun Ateş, 'Gece Döneminde Yapıllan Çalışmalar' (n 17) 87.

32 Bkz Ekmekçi, 'Postalar Halinde Çalıșma ve Gece Çalışması' (n 29) 51; Özyurt, 'Gece Çalıșması ve Postalar Halinde Çalışma' (n 2) 926; Okur, 'Gece Çalışması' (n 8) 513; Mülayim, Gece Çalışması (n 10) 141; Dursun Ateş, 'Gece Döneminde Yapılan Çalışmalar' (n 17) 86.

33 Okur, 'Gece Çalışması' (n 8) 512-513.
} 
postalar halinde çalışmalara ilişkin esasların düzenlendiği Yönetmelik’te (madde $7 /$ son) öngörülmüştür.

Öğretide, madde 7/son'daki kuralın postalar halinde çalışmanın söz konusu olmadığı gece çalışmaları bakımından da uygulanabileceği savunulmaktadır ${ }^{34}$. $\mathrm{Bu}$ yöndeki görüş benimsenir ise, örneğin saat 19.00-21.30 arasında yapılan bir çalışmanın da gece çalışması olarak nitelendirilmesi gerekecektir. Yüksek Mahkeme'nin ise bu konuda farklı yönde kararları mevcuttur. 7. Hukuk Dairesi’ne göre, eğer işyerindeki çalışma postalar halinde bir yapılan bir çalışma değil ise, işin yarısından fazlası gece döneminde geçse bile, çalışmanın tamamının gece çalışması niteliğinde sayılamaması gerekir ${ }^{35}$. 9. Hukuk Dairesi'nin bir kararında ise, gece bekçisi olarak çalışan iş̧̧inin günlük çalışma süresinin yarısından fazla bir kısmı gece dönemine denk gelen çalışmasının gece çalışması kabul edileceği belirtilmiş ve günlük fazla çalışma süresinin yedi buçuk saati aşılması üzerinden hesaplanması gerektiği sonucuna varılmıştır ${ }^{36}$.

Kanaatimizce, çalışma süresinin ne kadarlık bir kısmının gece dönemine rastlaması durumunda bu çalışmanın gece çalışması sayılacağının, yalnızca postalar halinde çalışmalar bakımından düzenlenmiş olması, önemli bir eksiklik niteliğindedir ${ }^{37}$. Gerçekten, gece çalışmasına ilişkin ayrıntılı düzenlemelere sadece postalar halinde çalışmaya ilişkin Yönetmelik’te yer verilmesi birtakım sorunlara yol açmaya elverişli olup, bu konu ileride, gece çalışma süresi sınırını esnekleştiren değişiklik ile bağlantılı olarak da değerlendirilecektir.

\section{Gece Çalışma Süresi Sınırını Esnekleștiren Son Değişikliklere İlişkin Değerlendirmeler}

Gece çalışması, pek çok tartışmaya zemin oluşturmuş bir çalışma düzenidir ${ }^{38}$. Gece çalışmasından vazgeçilmesinin mümkün olmadığı, toplumun gece çalışılmaksızın

34 Mülayim, Gece Çalışması (n 10) 142-144.

35 “...İ̧syerinde postalar halinde çalışma bulunmadığından işin yarısından fazlası gece döneminde geçse de çalışmanın tamamı gece çalışması niteliğinde sayılamayacaktır. Bilirkişice 14 saatlik çalı̧̧ma süresinden iki saat ara dinlenmesini orantı kurarak gece ve gündüz çalışmalarından indirmek suretiyle sonuca gitmesi gerekirken gece çalışmanın 69.madde düzenlemesine aykırı olarak 12 saat olarak kabulü hatalıdır...", bkz Yargıtay 7 HD, 24796/7184, 01.04.2014 (Lexpera).

36 Yargitay 9 HD, 17642/24006, 02.07.2015 (Kazanc1).

$37 \mathrm{Bu}$ anlamda, gece işçisi gibi bir kavrama yer verilerek, her bir işçi özelinde tereddüdü ortadan kaldıracak bir biçimde konunun açıklığa kavuşturulması bir çözüm olarak düșünülebilir. Ancak İș Kanunu'ndaki çalıșma sürelerine ilișkin hükümlerin Avrupa Birliği'nin çalışma sürelerine ilişkin direktifindeki (Council Directive 2003/88/EC of 4 November 2003 concerning certain aspects of the organisation of working time [2003] OJ L299/9) düzenlemeler dikkate alınarak hazırlanması nedeniyle bu iki mevzuat arasında belirli benzerlikler görülmesine rağmen (bkz Ertan İren, Avrupa Birliği İs Hukuku Yönergeleri Karşısında 4857 sayll İ̧̧ Kanununun Durumu (Çimento Endüstrisi İşverenleri Sendikası 2008) 230), İş Kanunu'nda ayrıca "gece işçisi” gibi bir kavrama yer verilmemiştir. Ekleyelim ki, Direktifin ikinci maddesinde yer verilen gece işçisi tanımına göre, günlük çalışma süresinin en az üç saatinin gece süresine rastladığı işçiler yahut yıllık çalışma süresinin belirli bir kısmının gece dönemine rastladığı işçiler gece işçisi olarak kabul edilmektedir. Bu kapsamda gece işçisi sayılabilmek için yıllık çalışma süresinin ne kadar kısmının gece dönemine rastlaması gerektiği üye ülkelerin mevzuatına bırakılmıştır.

38 Özveri, ‘Gece Çalışması'’ (n 8) 626. 
karşılanamayacak pek çok hizmeti bulunduğu ifade edilmekte ise de ${ }^{39}$, bu çalışmanın insanın biyolojik yapısına kural olarak ters düştüğü açıktır. Bu bakımdan gece çalışmasını yerine getirenler ile toplumun ihtiyaçları arasında bir denge gözetilmesinin gereği olarak, bu çalışma biçimine ilişkin pek çok sınırlandırıcı hüküm öngörülmüştür. Bunlardan biri de gece çalışma süresinin günlük sınırıdır. Bununla birlikte, 2015 yılında gece çalışma süresine ilişkin yedi buçuk saatlik süre sınırının (bkz. İş Kanunu madde 69/III), belirli işler bakımından aşılabilmesine imkân tanıyan bir mevzuat değişikliği gerçekleştirilmiştir $^{40}$. Buna göre; turizm, özel güvenlik ve sağlık hizmetlerinin yürütüldüğü işlerde, işçiden yazılı onayı almak şartı ile gece çalışmasına ilişkin yedi buçuk saatlik süre sınırının aşılması bir hukuka aykırılık teşkil etmeyecektir. Çalışmamızın bu bölümünde gece çalışma süresine ilişkin söz konusu değişikliğin daha yakından incelenmesi amaçlanmaktadır.

\section{A. Değişikliğin Hazırlık Sürecine Bakış}

Öğretide ifade edilen bir görüşe göre; turizm, özel güvenlik ve sağlık sektöründeki işler bakımından hizmet devamlılık gerektirmekte ve hizmetin kesintisizliği işin niteliğinden kaynaklanmaktadır ${ }^{41}$. Bu sektörlerdeki ihtiyaçlar günün her anında ortaya çıkabilecektir ve bu bakımdan çalışmanın hem gece hem gündüz döneminde yapılması bu hizmetin alıcıları için gereklilik arz etmektedir ${ }^{42}$. Anılan sektörlerdeki işlerin yürütülmesi bakımından, bu işyerlerinde faaliyetin devamlılığının sağlanmasına ihtiyaç duyulduğu yadsınamaz bir gerçek ise de, hizmetin devamlılığını sağlamanın tek yolunun, işçilerin gece çalışma sürelerini arttırmak olup olmadığı sorusu da gündeme gelebilir. Bu anlamda gece çalışma süresi sınırını bazı sektörler bakımından esneten değişikliğin değerlendirilebilmesi için, Kanun’un hazırlık aşamalarına da değinilmesi uygun görülmüştür.

Öncelikle, Kanun'un 69. maddesinde değişiklik yapan düzenlemeye, (1/1006 Esas Numaralı) İş Sağlığı ve Güvenliği Kanunu ile Bazı Kanun ve Kanun Hükmünde Kararnamelerde Değişiklik Yapılmasına Dair Kanun Tasarısı'nda ${ }^{43}$ yer verilmemiş olduğu belirtilmelidir. Bununla birlikte Alt Komisyon Metni'nin 40. maddesinde, İş Kanunu'nun 69. maddesinin 3. fikrasına “Ancak, sanayiden sayılmayan işlerde işçinin yazılı onayının alınması şartıyla yedi buçuk saatin üzerinde gece çalışması yaptırllabilir." cümlesinin eklenmesi öngörülmüştür ${ }^{44}$. Dikkat edileceği üzere Alt

39 Dursun Ateş, 'Gece Döneminde Yapılan Çalışmalar' (n 17) 82-83.

40 Bkz 6645 sayılı İş Sağlığı ve Güvenliği Kanunu ile Bazı Kanun ve Kanun Hükmünde Kararnamelerde Değişiklik Yapılmasina Dair Kanun madde 37.

41 Dursun Ateş, 'Gece Döneminde Yapılan Çalışmalar' (n 17) 83.

42 ibid 84

43 < https://www2.tbmm.gov.tr/d24/1/1-1006.pdf > Erişim Tarihi 15.08.2019.

44 Alt Komisyon Raporu'nda, “yürürlükteki mevzuata göre gece çalışmalarının yedi buçuk saat ile sinırlandırılmasının özellikle sağllk ve güvenlik sektörü işyerlerinde, iş̧̧iler açısından çeşitli sorunlara neden olduğu gerekçesiyle; işçilerin gece çalışmalarının yedi buçuk saati geçemeyeceğine dair hükme, sanayiden sayılmayan işler açısından bir istisna getirilmesi" öngörüldüğ̈̈nden söz edilmektedir, bkz: < https://www.tbmm.gov.tr/sirasayi/donem24/yil01/ss687.pdf > Erişim Tarihi 15.08.2019. 
Komisyon Raporu'nda getirilmesi planlanan bu istisna, ilk aşamada "sanayiden sayılmayan işlerin" tümüne ${ }^{45}$ ilişkin olarak düşünülmüştür. Ancak sanayiden sayılmayan işler bakımından işçiden yazılı onay almak şartıyla yedi buçuk saat üzerinde gece çalışması yaptırılabileceğine ilişkin söz konusu cümlenin eleştiriyle karşılandığı belirtilmelidir ${ }^{46}$. Fakat yine de Sağlık, Aile, Çalışma ve Sosyal İşler Komisyonunun Kabul Ettiği Metin'de “Ancak, sanayiden sayılmayan işlerde işçinin yazılı onayının alınması şartıyla yedi buçuk saatin üzerinde gece çalışması yaptırllabilir." cümlesi yer almış ve TBMM görüşmeleri sırasında bu düzenlemenin yeniden müzakere edilmesi önerisi reddedilerek madde bu hali ile kabul edilmiştir ${ }^{47}$. Ancak ertesi gün yapılan TBMM görüşmelerinde, kamu yararı çerçevesinde gece çalışmasına ilişkin bu hükmün kapsamının daraltılmasını da içeren yeni bir önerge verilmiş, "sanayiden sayılmayan” ibaresinin "turizm, özel güvenlik ve sağlık hizmeti yürütülen işler”" şeklinde değiştirilmesi kabul edilmiştir ${ }^{48}$. Gerekçe ise şu şekildedir:

"2003/88 sayıl AB Direktifinde, turizm özel güvenlik ve sağlık hizmetlerinde çalışanların gece çalışma süresinin sekiz saati üzerinde taraflarca anlaşllarak düzenlenebileceği belirtilmektedir. Düzenlemeyle, turizm, sağglk ve güvenlik sektörü işyerlerinin, sektörün ihtiyaçları doğrultusunda haftalık yasal çalı̧̧ma süresini geçmeyecek şekilde ve işçinin yazılı onayı alınarak gece çalışmalarındaki yedi buçuk saatlik günlük çalışma süresi sınırlamasına tabi olmaması amaçlanmıştır." ${ }^{49}$.

\section{B. Değişikliğe Avrupa Birliği Direktifi Perspektifinden Bakış}

Öğretide, İş Kanunu'nun 69. maddesinde 6645 sayılı Kanun ile getirilmiş olan belirli işlere yönelik istisnanın, çalışma sürelerine ilişkin 2003/88/EC sayılı Avrupa Birliği Direktifinde de mevcut olduğu ifade edilmektedir ${ }^{50}$. Gerçekten, Direktifin 17. maddesinin 3. fikrasında, -gece çalışma süresine ilişkin 8. madde de dahil olmak üzere- belirli faaliyetler / hizmetler bakımından bazı istisnalar düzenlenebileceği öngörülmüştür ve yine 17. maddede yer verilen istisnalar arasında, turizm, sağl1k ve güvenlik alanları ile bağlantılı faaliyetler de sayılmıştır.

Ancak önemle vurgulamak isteriz ki, istisnaların tanındığı söz konusu 17. maddenin 3. fikrasında, bu istisnalara 17. maddenin 2. fikrası uyarınca izin verildiğinden söz

\footnotetext{
Dikkat çekmek isteriz ki, raporda bu istisnanın “özellikle sağlık ve güvenlik sektörü işyerlerinde, işçiler açısından çeşitli sorunlara neden olduğu gerekçesiyle” getirilmek istenildiğine yer verilmiş, fakat turizm sektörü Alt Komisyon Raporu'nda bu aşamada henüz hiç anılmamıştır.

46 Bu konuda verilen muhalefet şerhlerinde, bir önerge ile sanayiden sayılmayan işyerlerinde gece çalışmasına ilişsin yedi buçuk saatlik sınırın kaldırılmasının, mevcut durum bakımından oldukça köklü bir değişiklik olduğu ve işçi haklarının geri götürülmesi anlamını taşıdığı ifade edilmiştir. Muhalefet şerhinde, bu düzenlemenin 2003/88 Sayılı Avrupa Parlamentosu ve Konseyi Direktifi ile uyumlu olmadığı, sanayiden sayılmayan işlerde çalışan tüm işçiler bakımından gece çalışma süresini 11 saate kadar artırabilen bir düzenlemeye gidildiği, bu şekilde gece ve gündüz çalışmaları arasında hiçbir fark kalmadığına yönelik açıklamalara da yer verilmiştir, bkz: < https://www.tbmm.gov.tr/sirasayi/donem24/yil01/ss687.pdf > Erişim Tarihi 15.08.2019.

$47<$ https://www.tbmm.gov.tr/tutanak/donem24/yil5/ham/b09001h.htm > Erişim Tarihi 15.08.2019.

$48<$ https://www.tbmm.gov.tr/tutanak/donem24/yil5/ham/b09101h.htm > Erişim Tarihi 15.08.2019.

$49<$ https://www.tbmm.gov.tr/tutanak/donem24/yil5/ham/b09101h.htm > Erişim Tarihi 15.08.2019.

50 Mülayim, Gece Çalı̧̧ması (n 10) 153-154.
} 
edilmektedir. Burada atıf yapılan 2. fikrada ise, ana kuraldan sapmalara ancak işçilere eşdeğer telafi edici dinlenme süreleri verildiğinde ya da çok istisnai durumlarda bu şekilde bir eşdeğer telafi edici bir sürenin objektif sebeplerle verilememesi halinde makul bir korumanın sağlanması kaydıyla izin verilmektedir. Bu bakımdan İș Kanunu'nun 69. maddesinde, böyle bir koruma öngörmeksizin sadece işçiden yazılı rıza almak şartıyla, sürekli bir biçimde işçinin gece çalışmasına ilişkin ana kural olan yedi buçuk saat üzerinde çalışma yapmasına izin veren kanun değiş̧ikliğinin, Avrupa Birliği hukuku ile bağdaştı̆̆ını söylemek güçtür ${ }^{51}$. Bu istisnalara söz konusu Direktif kapsamında da yer verildiği ifade edilmekte ise de, bu direktifte öngörülen eşdeğer bir koruma sağlanmadıkça, Avrupa Birliği mevzuatına uyumdan söz edilemeyeceği kanaatindeyiz.

\section{Değişikliğin Kapsamının Yalnızca Postalar Halinde Çalışmaya İlişkin Yönetmelikte Düzenlenmesi}

İş Kanunu'nun 69. maddesindeki değişiklik, mevzuatımızda yer alan başkaca düzenlemeleri de etkilemiş ve bazı düzenlemelerin revize edilmesi ihtiyacını doğurmuştur ${ }^{52}$. Bunlardan biri de işlerin postalar halinde işçi çalıştırılarak yürütülmesine ilişkin Yönetmelik’te (madde 7) yapılan değişikliktir ${ }^{53} .2017$ yılındaki Yönetmelik değişikliği ile ${ }^{54}$ postalar halinde işçi çalıştırılarak yürütülen işler bakımından özel güvenlik, turizm ve sağlık hizmetlerinin yürütüldüğü işlerin kapsamı düzenlenmiştir. Belirtmek gerekir ki, söz konusu düzenleme, özel güvenlik, turizm ve sağlık sektörlerinin kapsamına ilişkin tek düzenlemedir. Oysa, gece çalışmasının mutlaka postalar halinde bir çalışmanın parçası olması zorunluluğu yoktur. Böyle bir durumda, bir posta çalışması sistemi içerisinde olmaksızın sürekli bir biçimde gece çalışması yapan bir işçi bakımından da bu düzenlemeye kıyasen başvurulabileceği

51 Aksi görüşte bkz ibid 153-154. Yazara göre Kanun'a getirilen düzenleme esas itibarı ile Direktife aykırı nitelikte değildir.

52 Örneğin, nitelikleri nedeniyle sürekli çalıștıkları için kesintisiz olarak üst üste postalar halinde işçi çalıștırılarak yürütülen işlerde posta sayısı, kural olarak 24 saatlik süre içerisinde en az üç işçi postası çalıştırılacak şekilde düzenlenmektedir. Ancak postalar halinde çalışmaya ilişkin Yönetmelik'te yapılan değişiklik ile; turizm, özel güvenlik ve sağlık hizmetlerinin yürütüldüğü işlerde ve bu işlerin yürütüldügü işyerlerinde faaliyet gösteren alt işverence yürütülen işlerde 24 saat içerisinde iki posta şeklinde yapılabileceği öngörülmüştür. Öğretide henüz anılan Yönetmelik'e ilgili cümle eklenmeden önce de, 24 saatte en az üç posta şeklindeki sınırlamanın İş Kanunu madde 69/III kapsamındaki işçiler bakımından geçerliliğini yitirdiğine dikkat çekilmiştir. Yazara göre, madde kapsamındaki sektörler bakımından artık 24 saatte iki posta şeklinde çalışılması mümkün ise de, bu uygulama sürekli biçimde haftalık 45 saati aşan bir biçime dönüşmemelidir, bu yönde bkz Mahmut Kesici, 'Turizm, Özel Güvenlik ve Sağlık Hizmeti Yürütülen İşlerde Gece Çalışması' (2015) 47 Çalışma ve Toplum, 221, 231. Yine benzer şekilde, Kadın Çalışanların Gece Postalarında Çalıştırılma Koşulları Hakkında Yönetmelik de değişikliğe uğramış (bkz Kadın Çalışanların Gece Postalarında Çalıştırılma Koşulları Hakkında Yönetmelikte Değişiklik Yapılmasına Dair Yönetmelik RG 19.8.2017/30159), kadın çalışanların "her ne şekilde olursa olsun" gece postasında yedi buçuk saatten fazla çalıştırılamayacağına ilişkin kural (madde 5/1) revize edilerek, turizm, özel güvenlik ve sağlık hizmetlerinin yürütüldüğü işlerde ve bu işlerin yürütüldüğü işyerlerinde faaliyet gösteren alt işverence yürütülen işlerde kadın çalışandan yazılı onay almak şartı ile yedi buçuk saatin üzerinde gece çalışması yaptırılabileceği öngörülmüştür. Bununla birlikte eklemek gerekir ki, kadın çalışanların, gebe olduklarının doktor raporuyla tespit edilmesinden itibaren doğuma kadar, emziren kadın çalışanların ise doğum tarihinden başlamak üzere kendi mevzuatlarındaki hükümler saklı kalmak kaydıyla bir yıl süre ile gece postalarında çalıştırılamayacaklarına ilişkin düzenleme muhafaza edilmektedir (bkz madde 9).

53 Postalar Halinde İşçi Çalıştırılarak Yürütülen İşlerde Çalışmalara İlişkin Özel Usul ve Esaslar Hakkında Yönetmelikte Değişiklik Yapılmasına Dair Yönetmelik madde 2 (RG 19.8.2017/30159).

542017 yılında postalar halinde işçi çalıştırılmasına ilişkin Yönetmelik’te değişiklik yapılarak, getirilen istisna hükmünün uygulama alanına yönelik esaslara yer verilmeden önce öğretide, İş Kanunu'nun 69. maddesinde belirli sektörlere yer verilmesine rağmen bu hizmetlerin kapsamının belirtilmemiş olması hususu eleştiriye uğramış ve bu belirsizliğin uygulamada sorunlara yol açabileceğine dikkat çekilmiştir, bkz Kesici, ‘Gece Çalışması' (n 52) 223-227. 
savunulabilir ise de, gece çalışmalarına yönelik esasların büyük oranda yalnızca postalar halinde çalışmaya ilişkin Yönetmelik'te düzenlenmesi yönünde bir usulün yerleşmesini isabetli bulmadığımızı da belirtmek isteriz ${ }^{55}$.

\section{Değişikliğin İçeriğine İlişkin Bazı Değerlendirmeler}

\section{Yazılı Onay Sartı Bakımından}

Mevzuatımızda belirli sektörler bakımından yedi buçuk saatin üzerinde gece çalışması yapılabileceğine imkân tanıyan düzenlemede yazılı onay alınması gerektiğinden söz edilmekte ise de, onayın ne zaman alınması gerektiği belirtilmemiştir. Öğretideki bir görüşe göre, yazılı rızanın İş Kanunu madde 41 ve ona dayanılarak hazırlanmış olan İş Kanununa İlişsin Fazla Çalışma ve Fazla Sürelerle Çalışma Yönetmeliğ ${ }^{56}$ hükümleri çerçevesinde öngörülen usulde alınması gerekir ${ }^{57}$. $\mathrm{Bu}$ doğrultuda yazılı rıza, iş sözleşmesi yapılırken ya da ihtiyaç ortaya çıktığında alınır ${ }^{58}$ ve işçinin özlük dosyasında saklanır. Fazla çalışma yapmak istemeyen işçinin verdiği onayı otuz gün önceden işverene yazılı olarak bildirimde bulunmak şartı ile geri alabilmesi mümkündür ${ }^{59}$.

Önemle belirtmek gerekir ki, yazılı onay şartı, ispat değil, bir geçerlilik şartı niteliğindedir ${ }^{60}$. Öğretide her ne kadar bu rızanın toplu iş sözleşmeleri ile de alınmasının mümkün olduğu görüşü ileri sürülmüş ise $\mathrm{de}^{61}$, Kanun hükmünde yedi buçuk saatlik sınırın aşılmasının münhasıran işçinin rızasına bağlanmış olduğu açıktır. Bu bakımdan, çalı̧̧ma sürelerine ilişkin 2003/88/EC sayılı Avrupa Birliği Direktifini dikkate alarak yazılı onayın toplu iş sözleşmeleri ile de alınabileceği görüşünün ${ }^{62}$ isabet taşıdığı söylenemez. İş Kanunu madde 69/III hükmü istisnai nitelik taşıdığından ve bireysel olarak iş̧̧iden yazılı onay alınmasını aradığından, genel olarak toplu iş sözleşmeleri ile alınmış geçerli bir onayın varlığından söz edilmemelidir ${ }^{63}$.

\footnotetext{
$55 \mathrm{Bu}$ anlamda örneğin, çalışma süresinin yarısından fazlasının gece dönemine rastlaması durumunda bu çalışmanın gece çalışması sayılacağına yönelik düzenlemeye de yalnızca postalar halinde işçi çalıştırılmasına ilişkin Yönetmelik’te yer verilmiştir, bkz madde $7 /$ son.

56 İş Kanununa İlişkin Fazla Çalışma ve Fazla Sürelerle Çalışma Yönetmeliği, RG 6.4.2004/25425.

57 Kesici, 'Gece Çalıșması' (n 52) 230. Bu görüşün savunulduğu dönemde, İș Kanununa İlișkin Fazla Çalıșma ve Fazla Sürelerle Çalışma Yönetmeliği’ne fazla çalışma yaptırılacak işçinin onayına ilişsin maddede (bkz madde 9) henüz değişiklik gerçekleştirilmemiş idi. Yönetmelikte yapılan değişiklikten (bkz İş Kanununa İlişkin Fazla Çalışma Ve Fazla Sürelerle Çalışma Yönetmeliğinde Değişiklik Yapılmasına Dair Yönetmelik RG 25.8.2017/30165) önce kaleme alınan bu çalışmada, yazılı onayın başlangıçta iş sözleşmelerine bu yönde hüküm konularak alınabileceği ya da sonradan iş sözleşmesi devam ederken alınabileceği, işçiden alınmış yazılı onayın en fazla bir yıl için geçerli olacağı ve her yıl yenilenmesinin gerekeceği belirtilmiştir

58 Gece çalışmaları bakımından yedi buçuk saatin üzerinde çalışma yapılabilmesi için işçiden İș Kanunu madde 41 kapsamında alınmış onay yeterli olmayacağı yönünde bkz Çelik, Caniklioğlu and Canbolat, İş Hukuku (n 31) 710; Alpagut, 'Çalışma ve Dinlenme Süreleri' (n 17) 68.

59 Dursun Ateş, 'Gece Döneminde Yapılan Çalışmalar' (n 17) 104.

${ }^{6}$ Kesici, 'Gece Çalışması' (n 52) 229; Mülayim, Gece Çalışması (n 10) 159-160; Çelik, Caniklioğlu and Canbolat, İ̧ Hukuku (n 31) 710; Dursun Ateș, 'Gece Döneminde Yapılan Çalışmalar' (n 17) 103.

${ }^{61}$ Mülayim, Gece Çalışması (n 10) 162; Dursun Ateş, 'Gece Döneminde Yapılan Çalışmalar' (n 17) 104.

62 Bu görüşte bkz Dursun Ateş, 'Gece Döneminde Yapılan Çalışmalar' (n 17) 104.

63 Kesici, ‘Gece Çalışması' (n 52) 230 .
} 


\section{2. İşyerlerinin Esas Alınması Bakımından}

\section{a. Turizm, Özel Güvenlik, Sağlık Hizmeti İşlerinin Yürütüldüğüi İşyerleri}

Gece çalışmasının yedi buçuk saatin üzerinde yapılabilmesine izin verilen üç sektördeki işlerin kapsamı, işçilerin postalar halinde çalıştırılmasına ilişkin Yönetmelik'in 7. maddesinde belirlenmiştir. Öğretide, henüz Yönetmelik’te 2017 yılında bu konuya ilişkin değişiklik yapılmadan önce, niteliği itibariyle turizm, özel güvenlik ve sağlık hizmeti ile bağlantısı olan işlerin de bu kapsamda kabul görmesi gerektiği ifade edilmiştir ${ }^{64}$. Böylece, gece çalışmalarının yedi buçuk saati aşamamasının halen genel kural olduğunun gözden kaçırılmaması gerektiği ve bu nedenle genel kurala getirilen istisna kapsamında olan bağlantılı işlerin tespit edilirken ‘dar yorum ilkesinin' benimsenmesinin uygun olacağ 1 ileri sürülmüştür ${ }^{65}$.

Bununla birlikte, 2017 yılında yapılan Yönetmelik değişikliği ile; özel güvenlik, turizm ve sağlık hizmetlerinin yürütüldüğ̈̈ işlerin kapsamı belirlenirken; "tesisler", "işyerleri" ve "kuruluşlar" gibi ifadelere yer verilerek birimler esas alınmış ve buralarda çalışan işçiler bakımından -işçinin de onayının alınması şartı ile- yedi buçuk saati aşarak gece çalışması yapılabileceği öngörülmüştür. Özel güvenlik, turizm ve sağlık hizmetlerinin yürütüldüğü işlerin kapsamı belirlenirken yalnızca Yönetmelik hükmü esas alınacak olursa; burada her bir sektör bakımından birimler esas alınmış olduğundan ve bu birimlerde çalş̧an tüm işçiler kapsama dahil edildiğinden, örneğin sağlık hizmeti yürütülen bir işyerinde çalışan muhasebecinin de (yazılı onayını almak şartı ile) yedi buçuk saat üzerinde gece çalışması yapabileceğini kabul etmek gerekecektir. Oysa bu durumun Kanun'da öngörülen "sektörel” istisna ile bağdaşmayacağı açıktır. Nitekim Kanun' un hazırlık çalışmalarına da bakılacak olursa ${ }^{66}$, başlangıçta "sanayiden sayılmayan işlerde işçinin yazılı onayının alınması şartıyla yedi buçuk saatin üzerinde gece çalışmast yaptırllabilmesi" gündemde iken, verilen bir önerge doğrultusunda "sanayiden sayllmayan" ibaresinin "turizm, özel güvenlik ve sağllk hizmeti yürütülen işler" şeklinde daraltıldığ 1 da göz önünde tutulmalıdır ${ }^{67}$. O halde Yönetmelik hükmünü, Kanun'da öngörülen esasa aykırı olmayacak şekilde, İş Kanunu madde 69/III'te öngörülen özel güvenlik, turizm ve sağllk hizmetinin yürütüldüğ̈̈ bir işte çalışmak ön koşulu ile, Yönetmelik'in 7. maddesinde yer verilen birimlerin kapsamına alınmış işçiler olarak yorumlamak uygun olacaktır. Öğretideki aksi görüsşe göre ise, Yönetmelik’te “işler” sayılmayarak “işyerleri” esas alındığından, artık yapılan işin niteliği değil, çalıştığı işyeri dikkate alınarak gece döneminde yedi buçuk saatin üzerinde çalışma yapılıp yapılamayacağına bakılması gerekmektedir ${ }^{68}$.

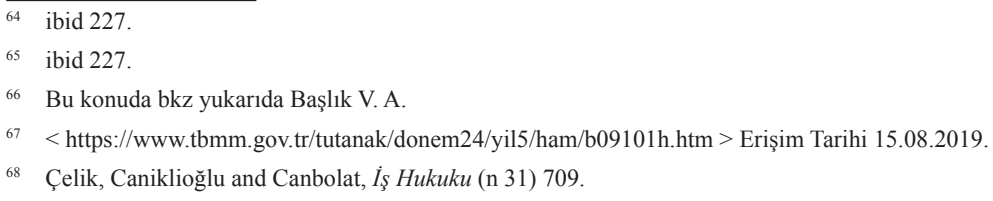




\section{b. Turizm, Özel Güvenlik, Sağlık Hizmeti İşlerinin Yürütüldüğü İşyerlerinde Alt İşveren Tarafından Çalıştırılan İşçiler}

İşçilerin postalar halinde çalıştırılması suretiyle yürütülen işlere ilişkin Yönetmelik'in 7. maddesinde ayrıca, Kanun metninde yer almayan bir ifadeye yer verildiği de belirtilmelidir. Yönetmelik’te yapılan değişiklik doğrultusunda; özel güvenlik, turizm ve sağlik hizmeti işlerinin yürütüldüğü işyerlerinde alt işveren tarafindan çallşstrılan iş̧̧ilerin de bu kapsamda olduğu öngörülmüştür. Öğretide, Yönetmelik'in 7. maddesinde bahsedilen işlerin "işyeri/işletme" esas alınarak belirlenmesi ve işçilerin tümünün kapsama alınmış olması nedeni ile, kapsam bakımından işyerlerinden iş alan alt işverenler tarafından çalıştırılan işçileri de içerecek genişlikte bir düzenlemenin söz konusu olduğu ileri sürülmüştür ${ }^{69}$.

Yönetmelik'te yer verilen ifadenin lafzı esas alınacak olursa; sağlık, turizm ve özel güvenlik sektörlerinde alt işveren tarafindan çalıştırılan tüm işçilere yedi buçuk saatin üzerinde gece çalışması yaptırılabileceği gibi bir sonuca ulaşlabilecektir. Oysa yine bu yönde bir yorumun da, Kanun'da öngörülen istisna hükmü ile bağdaşmayacağ 1 açıktır. Eğer turizm, sağlık ve özel güvenlik işlerinin görüldüğü işyerlerinde, alt işveren tarafından işçilerin tamamının gece yedi buçuk saat üzerinde çalıştırılabileceği kabul edilir ise, Yönetmelik hükmü Kanun'a aykırı bir biçimde yorumlanmış olur. Gerçekten Anayasa madde 124/I'de; Cumhurbaşkanının, Bakanlıkların ve kamu tüzel kişilerinin kendi görev alanları ile ilgili kanunların ve Cumhurbaşkanlığı kararnamelerinin uygulanmasını sağlamak için ve bunlara aykırı olmaması kaydıyla yönetmelikler çıkarabilecekleri hükmüne yer verilmiştir. Öğretide de yönetmelik çıkarmaya yetkili olanların, yönetmeliğin dayandığı yasa veya tüzükte öngörülmeyen bir sınırlamaya yer veremeyeceklerine isabetle dikkat çekilmektedir ${ }^{70}$. Aynı gerekçeyle, Yönetmelik'in, bir üst hukuk normunda getirilmiş olan istisna hükmünün kapsamını genişletmesi de hukuka uygunluk taşımayacaktır. Nitekim yakın tarihli Hukuk Genel Kurulu kararında da yer verildiği üzere; yönetmelik kaynağını kanundan almakta olup, yalnızca kanunun uygulanmasını göstermektedir. $\mathrm{Bu}$ nedenle kanunda bulunmayan bir düzenlemenin yönetmelik ile getirilmek yolu ile kanunun önüne geçecek şekilde uygulanmasının benimsenmesi hukukun genel teorisine aykırı niteliktedir ${ }^{71}$.

Görüşümüz göre, aynı doğrultuda, söz konusu Yönetmelik hükmünün de, yalnızca Kanun'da yer verilen sektörler bakımından alt işverenlik ilişkisi kurulduğu

\footnotetext{
ibid 709; Dursun Ateş, 'Gece Döneminde Yapılan Çalışmalar' (n 17) 99.

70 Ömer Ekmekçi, Toplu Işs Sözleşmesiyle Düzenleme Yetkisi, (BANKSíS 1996) 66-67.

${ }^{71}$ "Diğer taraftan normlar hiyerarşisi dikkate alındı̆̆ında daha alt basamakta yer alan ve tamamen idarenin düzenleyici tasarrufu niteliğinde olan yönetmelikle, daha üst basamakta bulunan ve yasama organı tarafindan objektif, soyut ve genel nitelikte bir yasama tasarrufu niteliğinde bulunan kanuna aykırl düzenleme getirilmesi mümkün değildir. Yönetmelik kaynağını kanundan alır ve ancak kanunun uygulanmasını gösterir. Kanunda bulunmayan bir düzenlemenin, yönetmelikle ihdası ve bu yolla kanunun önüne geçen bir uygulamanın benimsenmesi hukukun genel teorisine de aykırıdır.", Hukuk Genel Kurulu, 22-2381/2038, 27.12.2017 (Kazanc1).
} 
durumlara özgü olarak, bu alanlarda iş alan alt işveren işçilerini kapsayacak şekilde yorumlanması gerekir. Bu şekilde örneğin, bir hastanede hem yemek işinin hem de güvenlik işinin alt işverene verildiği bir kurguda, alt işverence çalıştırılan özel güvenlik personeline yedi buçuk saat üzerinde gece çalışması yaptırılabilecek iken; alt işverence çalıştırılan yemekhane personelinin yazılı onayı alınmış olsa bile gece yedi buçuk saat üzerinde çalıştırılması hukuka uygun olmayacaktır.

\section{E. Gece Çalışma Süresinin Aşılması ve Durumun Fazla Çalışma Ücreti Bakımından Değerlendirilmesi}

İş Kanunu'nun 104. maddesinde, Kanun'un 69. maddesine aykırılı̆̆ın yaptırımı olarak idari para cezası öngörülmüştür. Ancak eklemek gerekir ki, Yargıtay içtihatları, gece çalışmasının günde yedi buçuk saati geçemeyeceğine ilişkin hükme aykırılığın, aynı zamanda aşılan çalışma süresi bakımından işçinin fazla çalışma ücretine hak kazandıran bir durum olduğu yönündedir. Öğretide bu yaklaşımı isabetli bulanlar olduğu gibi ${ }^{72}$, eleştirenler de bulunmaktadır ${ }^{73}$. Yüksek Mahkeme'nin yerleşik içtihadına göre, fazla çalışma ücretine hak kazanmak için yedi buçuk saat sınırının aşılması yeterli olup, haftalık 45 saat olan yasal çalışma süresinin aşılmasına ihtiyaç bulunmamaktadir ${ }^{74}$.

Bu noktada, 2015 yılında gece çalışma süresinin günlük sınırının turizm, özel güvenlik, sağlık hizmeti yürütülen işlerde değişikliğe uğramış olması nedeni ile, bu sektörlerde yedi buçuk saatin aşılması durumunda işçinin fazla çalışma ücretine hak kazanıp kazanamayacağı konusunun ayrıca değerlendirilmesi gereği doğmuştur ${ }^{75}$. Tespit edebildiğimiz kadarıyla, bu değişiklikten sonra anılan sektörlerde çalışanlar bakımından bu durumun değerlendirildiği bir karar henüz yayımlanmamıştır. Yakın geçmişte Yüksek Mahkemenin sağlık sektöründe çalışan bir işçinin alacaklarına ilişkin kararında, 6645 sayılı Kanun ile İş Kanunu'nda yapılan değişikliğe yer verilmiş ise de, davacı işçinin hizmet süresi döneminde bu değişikliğin yürürlükte olmaması nedeniyle konuya ilişkin başkaca bir değerlendirme yapılmamış, yalnızca bu dönemde yedi buçuk saatlik gece mesai süresine uyulması gerektiğine dikkat çekmiştir ${ }^{76}$.

\footnotetext{
Güven and Aydın, Bireysel İş Hukuku (n 8) 275; Özveri, ‘Gece Çalışması' (n 8) 640.

73 Gece döneminde yapılan çalışmanın yedi buçuk saatin üzerine çıktığı, ancak haftalık toplam çalışma süresinin 45 saate ulaşmadığı durumlarda, işçinin fazla çalışma ücretine hak kazanamayacağı yönündeki görüşe göre, iş hukukunda işçinin korunması gereğine yönelik sosyal düşünceler fazla çalışmaya yönelik emredici hükmün yorum yoluyla aşılması için yeterli bir sebep teşkil etmemektedir, Astarlı, Çalışma Süreleri (n 9) 259. Belirli sektörler bakımından yedi buçuk saatin üzerinde çalışma yapılmasına ilişkin istisnai düzenlemenin yürürlüğe girmemiş olduğu dönemde ileri sürülen bu görüşe göre, günlük yedi buçuk saatin üzerinde gece çalışma yapılmasının yaptırımı idari para cezasının uygulanmasıdır, bkz Astarlı, Çalışma Süreleri (n 9) 259.

74 "Yine iş̧̧ilerin gece çalışmaları günde yedibuçuk saat geçemez (İ̧̧, Kanunu, Md 69/3). Bu durum günlük çalı̧̧manın dolayısıyla fazla çalıșmanın sinırını olușturur. Gece çalıșmaları yönünden, haftalık kırkbeș saat olan yasal çalıșma sinır aşılmamış olsa da günde yedibuçuk saat aşan çalışmalar için fazla çalışma ücret ödenmelidir. Dairemizin kararları da bu yöndedir.”, bkz Yargitay 22 HD, 10297/8986, 17.04.2019 (Kazanc1); Yargitay 22 HD, 22348/10567, 14.05.2019 (Kazanc1).

75 Dursun Ateş, 'Gece Döneminde Yapılan Çalışmalar' (n 17) 84.

76 Yargitay $22 \mathrm{HD}, 18121 / 25703,28.11 .2018$ (Kazanc1).
} 
Öğretide, İş Kanunu'nun 69. maddesinde belirli sektörlerde gece yedi buçuk saatin üzerinde çalışılması için işçiden yazılı onay alınması gerektiğinin şart koşulmuş olması nedeniyle, anılan işlerde çalışan işçinin yazılı onay vermemesi durumunda ve günlük yedi buçuk saat sınırı aşıldığında, işçinin yerleşik yargı içtihadına istinaden fazla çalışma ücretine hak kazanacağı kabul edilmektedir ${ }^{77}$. İşçinin yedi buçuk saat üzerinde çalışmaya yazılı onay vermesi ihtimali bakımından ise durum tartışmalıdır. Yazılı onayın varlığı halinde, söz konusu çalışmanın artık kanuna aykııı bir nitelik taşımadığ $\operatorname{tartışmasız~ise~} \mathrm{de}^{78}$, bu durumdaki işçinin fazla çalışma ücretine hak kazanıp kazanamayacağı konusuna öğretide farklı şekilde yaklaşılmaktadır. Bir görüşe göre, iş̧̧inin gece yedi buçuk saatin üzerinde çalışmaya verdiği onay yalnızca yedi buçuk saatin üzerinde çalışmaya ilişkindir, yoksa işçinin fazla çalışma ücretinden feragat ettiği düşünülmemelidir ${ }^{79}$. Bunun nedeni, fazla çalışmaya yazılı onay vermemiş olan işçiler ile yazılı onay vermiş işçilerin yedi buçuk saatin üzerinde çalıştırılması durumunda, ücret bakımından ayrıma yol açılmasının kabul edilebilir olmamasıdır $^{80}$. Diğer görüsşe göreyse, söz konusu Kanun değişikliğinden sonra yazılı onay ile çalışma süresinin uzatılması öngörüldüğü için, işçiler onay verilmiş olan çalışma süresi aşılmadıkça fazla çalışma ücretine hak kazanamayacaklardır ${ }^{81}$.

Görüşümüze göre de, artık belirli sektörler bakımından gece çalışma süresinin yedi buçuk saatin üzerine çıkmasının (işçinin de yazılı onayını almak şartıyla) yasal hale gelmiş olması nedeniyle, bu durumdaki bir işçinin günlük yedi buçuk saat üzerinde gece çalışması yapması nedeniyle fazla çalışma ücretine hak kazanacağını savunmak güç gözükmektedir. Haftalık çalışma süresi aşılmamasına rağmen günlük gece çalışma süresi sınırının aşılması durumunda işçinin fazla çalışma ücretine hak kazanması gerektiği yönündeki görüş, Kanun'un yasakladığı bir çalışmanın yaptırımının sadece idari para cezası ile sınırlanmasının yeterli görülmemesi, işçiyi korumak için getirilmiş bir düzenlemenin işçi aleyhine sonuçlar doğurmasının önüne geçilmesi ile bağlantılıdır ${ }^{82}$. Bu nedenle, katıldığımız görüşe göre de, eğer yazılı onay almak şartı da sağlanmış ise Kanun'a aykırı bir durumdan söz edilemeyeceğinden, günlük gece çalışma süresi sınırının aşılmasının yaptırımı artık fazla çalı̧̧ma ücretine hak kazanmak olmamalıdır. Bununla birlikte açıktır ki, İş Kanunu madde 69/III'teki istisna kapsamında olan bir iş̧̧inin gece çalışma süresi, günlük en fazla çalışma sınırını ya da haftalık çalışma sınırını aşmış ise, işçinin fazla çalışma ücretine hak kazanması bakımından bir değişikliğin gündeme gelmemesi gerekir.

\footnotetext{
Kesici, 'Gece Çalışması'’ (n 52) 232; Mülayim, Gece Çalışması (n 10) 161.

78 Kesici, 'Gece Çalışması' (n 52) 232.

79 ibid 232.

80 ibid 232.

${ }^{81}$ Mülayim, Gece Çalışmass (n 10) 161; Çelik, Caniklioğlu and Canbolat, İşs Hukuku (n 31) 710; Dursun Ateş, 'Gece Döneminde Yapılan Çalışmalar' (n 17) 119; Alpagut, 'Çalışma ve Dinlenme Süreleri' (n 17) 69.

82 Özveri, ‘Gece Çalışması' (n 8) 640.
} 


\section{Sonuç}

Gece çalışması, insanın doğası gereği uyuması gereken saatlerde yapılan bir çalışma olması nedeniyle, özel hükümler ile düzenlenen bir çalışma biçimidir. Bu anlamda gece döneminde yapılan çalışmalar ile gündüz döneminde yapılan çalışmaların aynı şekilde ele alınmaması beklenir. Bu doğrultuda çalışmamızda öncelikle gece çalışmasının özellikleri üzerinde durulmuş ve mevcut düzenlemeler bakımından tespit edilen bazı hususlara ilişkin önerilerde bulunulmuştur. Örneğin mevzuatımız gereğince ara dinlenmeleri çalışma süresinden sayılamaz ise de, gece çalışmasında bulunan bir işçi ara dinlenmesinde aynı zamanda biyolojik yapısına ters düşen bir biçimde gün 1şığından yoksun bir şekilde geçireceği süreyi de uzattığından, gece çalışmasında ara dinlenmesi süresinin çalışma süresine dâhil edilmesi düşünülebilir. Gerçekten, iş sağlığı ve güvenliği hukuku alanındaki gelişmeler ve gece çalışmasının insan sağlığı üzerindeki etkilerine ilişkin araştırmalar, gece çalışmasına yönelik düzenlemelerin gözden geçirilmesini ve iyileştirilmesini zorunlu kılmaktadır.

$\mathrm{Bu}$ anlamda gece çalışmasında bulunan işçiler bakımından koruyucu hükümler arasında belki de en önemlisi, gece çalışma süresine ilişkin getirilmiş sınırdır. Ancak gece çalışma süresine ilişkin yedi buçuk saatlik sınırın üzerine çıkılabilmesi, 2015 yılında gerçekleştirilen Kanun değişikliği ile, işçinin yazılı onayını almak şartına bağlı olarak, özel güvenlik, turizm ve sağlık hizmeti yürütülen işlerde yasal hale gelmiştir. Kanaatimizce, bu değişiklik işçinin korunmasının sağlanması bakımından bir geriye gidiş olarak nitelendirilebilir. Her ne kadar yedi buçuk saatin üzerinde çalışma yapılabilmesi için iş̧̧inin yazılı onayı şart koşulmuş ise de, iş hukukunun -özellikle de iş sağllğ 1 ve güvenliği hukuku ile bağlantılı noktalarda- işçiyi kendisine rağmen koruyan bir yaklaşımı olduğu gözden uzak tutulmamalıdır. Madde metninde yer verilen sektörlerde hizmetin kesintisiz devam etmesi gerektiği savunulabilecek ise de, hizmetin devamlılığını sağlamanın tek çözümü işçinin daha uzun süreli çalıştırılması değildir. Hizmetlerin kesintisiz bir biçimde sürdürülebilmesinin, vardiya sayısının arttırılması ile de sağlanabileceği açıktır. Üstelik, çalışmamızda yer verdiğimiz üzere, söz konusu değişikliğin 2003/88/EC sayılı Avrupa Birliği Direktifi ile de uyumlu olduğu söylenememektedir. Öte yandan önemle vurgulamak isteriz ki, postalar halinde işçi çalıştırılarak yürütülen işlerdeki çalışmalar için çıkarılan Yönetmelik'te gece çalışma süresine yönelik istisna hükmüne ilişkin kapsamın, tesis, işyeri, kuruluş ifadelerine yer verilerek belirlenmesi de eleştiriye açıktır. Kapsamın belirlenmesi bakımından yorumun Kanun'daki istisna hükmü ile bağdaşacak biçimde yapılması gerektiği kanaatindeyiz.

Bunun dışında, mevzuatımızda gece çalışmasına yönelik önemli esasların yalnızca postalar halinde işçi çalıştırılarak yürütülen işlere ilişkin Yönetmelik ile düzenlendiği dikkat çekmektedir. Ancak gece çalışmasının postalar halinde yürütülmediği işler de bulunduğundan, gece çalışmasına ilişkin birtakım önemli esaslara yalnızca bu Yönetmelik çerçevesinde yer verilmesini isabetli bulmadığımızı ifade etmek isteriz. 
Sonuç olarak çalışmamızda, mevzuatımızda gece çalışmalarına ilişkin düzenlemelerin gözden geçirilmesi ihtiyacı bulunduğu kanaatine ulaşılmıştır. $\mathrm{Bu}$ noktada, gece çalışmasına ilişkin olarak düzenlemelerin oldukça dağınık bir halde yer aldığına dikkat çekerek ${ }^{83}$, gece çalışmasına ilişkin tüm esasların tek bir yönetmelik kapsamında düzenlenmesini önermek isteriz. Hatta belki bir adım daha ileri gidilerek, bu yönetmeliğin İş Sağlığı ve Güvenliği Kanunu'na dayanılarak çıkarılması üzerinde düşünülebilir ${ }^{84}$. Bu şekilde, iş̧̧inin İş Kanunlarının hangisine tabi olduğuna ya da Borçlar Kanunu'na tabi olup olmadığına bakılmaksızın, gece çalışması söz konusu olduğunda asgari bir koruma altında olabilmesi de sağlanabilecektir. Bu durum, görülen işin niteliğinden kaynaklanan ayrıksı düzenlemelerin gözetilmesine engel olmayacağı gibi, mevzuatımızda dağınık bir halde yer alan gece çalışmasına ilişkin pek çok düzenlemenin de derlenmesine imkân tanıyacaktır.

Finansal Destek: Yazar bu çalışma için finansal destek almamıştır.

83 Örneğin, 18 yaşını doldurmamış çocuk ve genç işçiler, İş Kanunu'nda tanımlanan gece dönemine denk düşen 20.00-06.00 saatleri arasındaki işçi postalarında çalıștırılamaması, hem Postalar Halinde İşçi Çalıştırılarak Yürütülen İşslerde Çalıșmalar Yönetmelik (RG 7.4.2004/25426) madde 5/I’te hem de Çocuk ve Genç İşçilerin Çalıştırılma Usul ve Esasları Hakkında Yönetmelik (RG 6.4.2004/25425) madde 5/VI’te öngörülmektedir.

84 Nitekim Kadın Çalışanların Gece Postalarında Çalıștırılma Koşulları Hakkında Yönetmelik (RG 24.7.2013/28717), hem 4857 sayılı İş Kanunu'nun 73. maddesine hem de 6331 sayı1ı İş Sağlı̆̆ ve Güvenliği Kanunu'nun 30. maddesine dayanılarak çıkarılmıștır. Anılan Yönetmelik, uygulama bakımından öncelik olarak çalıșanın tabi olduğu ilgili mevzuat hükümlerinin dikkate alınması gerektiğini, 6331 sayılı İş Sağlığı ve Güvenliği Kanunu kapsamında olup kendi özel mevzuatlarında hüküm bulunmaması halinde ise bu Yönetmelik hükümlerinin uygulanacağını (bkz madde 11) öngörmektedir. 


\section{Bibliyografya/Bibliography}

Alpagut G, 'İ̧̧ Kanunu Kapsamında Çalı̧̧ma ve Dinlenme Süreleri - Yargılama Sürecinde Emsal Ücret Sorunu', Işs Uyuşmazlıklarında Yargıtay ve Bölge Adliye Mahkemeleri Kararları Değerlendirme Toplantısı, (INTES 2019) 67-89.

Astarlı M, İş Hukukunda Çalışma Süreleri (Turhan 2008).

Bacak B and Kazancı E, 'Türk Çalışma Hayatında Vardiyalı Gece Çalışan İşçilerin Karşılaştığı Fizyolojik, Psikolojik Ve Sosyolojik Etkilerin Değerlendirilmesi' (2014) 3 (6) Emek ve Toplum, 132-149.

Çelik N, Caniklioğlu N and Canbolat T, $\dot{I}_{S ̧}$ Hukuku Dersleri (32th edn, Beta 2019).

Demir F, En Son Yargıtay Kararları Işı̆̆ında İş Hukuku Ve Uygulaması, (8th edn, Albi 2014).

Dursun Ateş S, 'Turizm, Özel Güvenlik Ve Sağlık Hizmeti Yürütülen İşlerde Gece Döneminde Yapılan Çalışmalar’ (2019) 16 (61) Legal İHSGHD 81-126.

Ekmekçi Ö, Toplu İş Sözleşmesiyle Düzenleme Yetkisi (BANKSİS 1996).

Ekmekçi Ö, ‘4857 Sayılı İş Kanunu'nda Postalar Halinde Çalışma ve Gece Çalışmasına İlişkin Usul ve Esaslar' (2006) Çimento İşveren, 48-55. (Postalar Halinde Çalışma ve Gece Çalışması)

Ekonomi M, Iş̧ Hukuku, Cilt 1, (3rd edn, Teknik Üniversitesi Matbaası 1984).

Eyrenci Ö, Taşkent, S and Ulucan D, Bireysel İş Hukuku, (9th edn, Beta 2019).

Güven E and Aydın U, Bireysel Işs Hukuku, (5th edn, Nisan 2017).

İren E, Avrupa Birliği İş Hukuku Yönergeleri Karşısında 4857 sayılı İş Kanununun Durumu, (Çimento Endüstrisi İşverenleri Sendikası 2008) .

Kesici M, ‘Turizm, Özel Güvenlik ve Sağlık Hizmeti Yürütülen İşlerde Gece Çalışması' (2015) 47 Çalışma ve Toplum, 221-235.

Mollamahmutoğlu H, Astarlı M and Baysal U, İş Hukuku Ders Kitabı, Cilt 1: Bireysel Işs Hukuku, (3rd edn Lykeion 2019).

Mülayim BO, İş Hukukunda Gece Çalışması (Adalet 2016).

Odaman S, Esneklik Prensibi Çerçevesinde Yargıtay Kararları Işı̆̆ı̆nda Türk İş Hukukunda Çalışma Süreleri ve Yöntemleri (Legal 2013).

Okur Z, 'İş Hukuku'nda Gece Çalışması', Prof. Dr. Ali Güzel'e Armağan, Cilt I (Beta 2010) 511-569.

Özveri M, 'Çalışma Süresi ve Gece Çalışması', Prof. Dr. Ali Güzel'e Armağan, Cilt I (Beta 2010) 623-645.

Özyurt V, 'Gece Çalışması ve Postalar Halinde Çalışma' (2008) 5 (19) Legal İHSGHD 919-955.

Saracel N, Gece Çalışması ve Türk Işs Hukukunda Gece Çalışmasının Düzenlenme Esasları, (T.C. Anadolu Üniversitesi Yayınlar1 1987).

Senyen- Kaplan ET, Bireysel İş Hukuku (10th edn, Gazi 2019).

Süzek S, İş Hukuku (18th edn, Beta 2019).

\section{Çevrimiçi Kaynaklar}

https://www.kazanci.com.tr/ (Kazanc1)

http://www.lexpera.com.tr/ (Lexpera)

https://www2.tbmm.gov.tr/d24/1/1-1006.pdf

https://www.tbmm.gov.tr/sirasayi/donem24/yil01/ss687.pdf

https://www.tbmm.gov.tr/tutanak/donem24/yil5/ham/b09001h.htm 